\title{
In Memorium: Thomas Hilker
}

\author{
Alexei I. Lyapustin ${ }^{1}{ }^{*}$, Nicholas. C. Coops ${ }^{2}$, Forrest G. Hall ${ }^{1}$, Compton J. Tucker ${ }^{1}$, \\ Piers J. Sellers ${ }^{1}$, Lenio Soares Galvão ${ }^{3}$, Luiz E. O. C. Aragão ${ }^{3}$, Liana O. Anderson ${ }^{3}$, \\ Caroline J. Nichol $^{4}$ and Richard H. Waring ${ }^{5}$ \\ 1 NASA Goddard Space Flight Center, Greenbelt, MD 20771, USA; forrest.g.hall@nasa.gov (F.G.H.); \\ compton.j.tucker@nasa.gov (C.J.T.); piers.j.sellers@nasa.gov (P.J.S.) \\ 2 University of British Columbia, Vancouver, BC V6T 1Z4, Canada; nicholas.coops@ubc.ca \\ 3 National Institute for Space Research (INPE), São José dos Campos 12227-010, Brazil; \\ lenio.galvao@inpe.br (L.S.G.); laragao@dsr.inpe.br (L.E.O.C.A.); liana.anderson@cemaden.gov.br (L.O.A.) \\ * Correspondence: alexei.i.lyapustin@nasa.gov; Tel.: +1-301-614-5998 \\ Academic Editor: Prasad S. Thenkabail \\ Received: 8 October 2016; Accepted: 12 October 2016; Published: 17 October 2016
}

Dr. Thomas Hilker left us on 4 September 2016 following a sudden cardiac arrest. Thomas was a devoted husband to Yhasmin, and a brother and son to his family in Germany to whom we express our deepest sympathies. Friends and colleagues of Thomas in the remote sensing and ecological communities lament this tragic loss. During his short but stellar science career, Thomas became a world leader in the field of carbon, water and energy exchange from the land. He pioneered studies in the Amazonian forests, using anisotropy information acquired from satellites to describe three-dimensional structures that linked these ecosystems functionally to climatic variation.

Thomas had an extreme range of interests-from the engineering of advanced spectrometers to providing new theories and innovative methods to process remotely sensed data. Dr. Piers Sellers, Acting Director of the Earth Sciences Division at NASA/GSFC, and Deputy Director of the Sciences and Exploration Directorate wrote: “Thomas Hilker was something of a renaissance man in Earth Science. He could climb towers, measure tall trees, and calculate spectral indices in his head. Working with him was like collaborating with two or three normal people. He had some of the best and most original ideas in remote sensing that I've come across, but unlike most of us, he could go get the data to prove his point. And he was always the best fun. I remember him coming to a couple of parties of ours-he was always relaxed, humorous, charming. He could make people laugh and everyone felt so good around him."

Thomas obtained a Bachelor of Science degree in Forestry from the University of Applied Sciences, in Goettingen, Germany in 2000, a Master in Photogrammetry and Geoinformatics from the University of Applied Sciences in Stuttgart in 2002 and a PhD from the University of British Columbia (UBC) in Forestry in 2008. After a three year postdoctoral position at UBC (2008-2011), he worked as a Research Associate at NASA's Goddard Space Flight Center (2011-2012). From 2012 to 2016, Thomas held a position as Assistant Professor at Oregon State University's College of Forestry, leading the Remote Sensing Laboratory and teaching classes in Remote Sensing and Spatial Data Analysis. In 2015 and 2016 he was a visiting researcher at the National Institute for Space Studies in Brazil (Instituto Nacional de Pesquisas Espaciais, INPE). He looked forward to starting a position as an Associate Professor of Earth System Science and Remote Sensing at the University of Southampton, UK.

Thomas became fascinated by the global carbon cycle following receipt of his Master's degree and was keen to utilize his geospatial skills to unlock the details of the cycle. Inspired by the links between canopy reflectance and photosynthesis, Thomas designed an Automated Multiangular Spectroradiometer for Estimation of Canopy reflectance [1] and improved it in subsequent iterations $[2,3]$ to be able to continuously monitor subtle changes in the reflected spectra from 
forest canopies. Appreciating the potential of a photochemical reflectance index (PRI) developed by Gamon et al. [4] to indicate when the photosynthetic process was down-regulated, Thomas, supported by the Canadian Carbon Program (CCP), developed new techniques for processing spectral data acquired from multi-angular observations. Changes in spectral bi-directional reflectance (BRDF) help derive remotely sensed estimates of gross primary productivity (GPP) in close agreement with that measured at a number of eddy-flux tower sites in Canada $[5,6]$.

In his $\mathrm{PhD}$ dissertation, he found a way to measure and describe forest structure in striking detail using airborne Light Detection and Ranging (LiDAR) data. His innovative approach helped to explain differences measured in net ecosystem production at a range of forest sites [7]. For this effort, Thomas was jointly awarded the best PhD thesis in 2008 by the Canadian Remote Sensing Society (CRSS).

Thomas enjoyed the elegant simplicity of laser return data and completed a number of studies examining how airborne and ground-based laser scanning could be used to provide insights into ecological processes as well as estimates of productivity in lodgepole-pine and Douglas-forests $[8,9]$. His work with LiDAR continued after his $\mathrm{PhD}$ [10] and at Oregon State University he continued to examine uncertainties in above ground biomass estimates from LiDAR [11] and that fused with other sensors such as Landsat [12]. He also developed an approach to effectively fuse Landsat and MODIS imagery, in what has become his highest cited paper to date [13].

Joining NASA in 2009, Thomas, collaborating with a group of established scientists, built the theoretical foundations for a satellite that could carry instruments to sense constraints on photosynthesis (light-use-efficiency), which could be compared with measurements acquired at tower sites and expanded to encompass all terrestrial vegetation [14-19].

Thomas was intrigued by the ongoing controversy around the dry-season greening of the Amazon forests. As a result, he led a MODIS-based analysis that demonstrated a strong correlation of the remotely sensed greening and browning anomalies of the Amazonian rainforest with the short-term climate variability as expressed in the ENSO index [20]. The power of multi-angle satellite observations of vegetation properties to estimate photosynthesis and other key processes encouraged Thomas to join the National Institute for Space Research in Brazil as a visiting scientist in 2014 and establish important collaborations with Brazilian scientists. With their help, and that of colleagues at Goddard Space Flight Center, he developed the project "MAPS: Multi-angle Amazon Physiology and Structure" funded by the Conselho Nacional de Desenvolvimento Cientifico e Tecnológico (CNPq), as part of the Brazilian program "Science without Borders". Previous studies had demonstrated the high sensitivity of the Enhanced Vegetation Index (EVI) to differences in view-illumination geometry. While conventionally, this BRDF effect was considered as a "noise" in the MODIS time series, Hilker and colleagues proposed a unique approach using EVI anisotropy as a source of information on canopy structure in the Amazon [21]. Seasonality and drought effects were quantified using directional information obtained from the EVI in MODIS forward scattering and backscattering view directions. This step was preceded by a careful definition of the length of the dry season over the different regions of the Amazon.

Within the scope of the MAPS project, Thomas was striving to develop a first-principle way to characterize vegetation using spectral reflectance in place of more conventional vegetation indices. Atmospherically corrected data from Multi-Angle Implementation of Atmospheric Correction (MAIAC) algorithm [17] in MODIS bands 1-12 were used to invert the fully-coupled canopy reflectance model ProSAIL to estimate monthly canopy chemistry (carotenoids, canopy water, and nitrogen content) focusing the analysis on chlorophyll [22]. The results showed strong seasonal variations in ProSAIL-derived pigment estimates in central Amazon with marked increases in chlorophyll concentrations early during the dry season. Hilker concluded that vegetation phenology, rather than changes in sunlight, directly controls seasonality of plant productivity across the region. This pioneering work allowed Thomas to experience in loco the intensity of Amazon forest functioning. Thomas's sharp ideas on using multi-angular information for studying Amazon forest processes will 
be eternized by his legacy of scientific writings and passionate engagement with students and scientists during his time in Brazil.

Thomas was on the editorial board of Remote Sensing of Environment and a dedicated reviewer for a large number of Forestry and Remote Sensing journals. He served on the Scientific Committee of the XVII Symposium on Brazilian Remote Sensing (SBRS) and was the organizer of Special Sessions on XVII SBRS held in 2015 and on the next XVIII SBRS to be held in 2017.

In his own way, Thomas had an irresistible personality—kind and humble, always smiling and in good humor. In combination with his engaging and sharp mind, and boundless enthusiasm for his work, he drew many researches into his orbit starting multiple collaborations. In every place he worked, he rapidly became a reference for students and researchers who sought his scientific advice.

Each of us, blessed with a chance to meet and work with Dr. Hilker, have benefitted immeasurably from the opportunity, and his scientific legacy will benefit future generations. We will miss you, Thomas, brilliant scientist, amazing friend and wonderful human being.

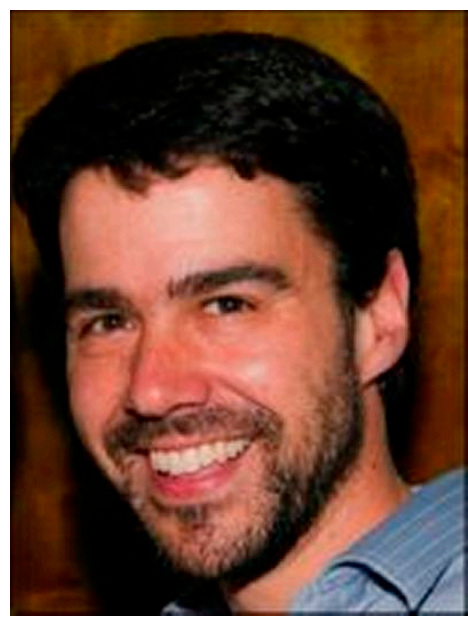

Conflicts of Interest: The authors declare no conflict of interest.

\section{References}

1. Hilker, T.; Coops, N.C.; Nesic, Z.; Wulder, M.A.; Black, T.A. Instrumentation and approach for unattended year round tower based measurements of spectral reflectance. Comput. Electron. Agric. 2007, 56, 72-84. [CrossRef]

2. Hilker, T.; Nesic, Z.; Coops, N.C.; Lessard, D. A new automated multi-angular radiometer instrument for tower based observations of canopy reflectance (AMSPEC II). Instrum. Sci. Technol. 2010, 38, 319-340. [CrossRef]

3. Tortini, R.; Hilker, T.; Coops, N.C.; Nesic, Z. Technological advancement in tower-based canopy reflectance monitoring: The AMSPEC-III system. Sensors 2015, 15, 32020-32030. [CrossRef] [PubMed]

4. Gamon, J.A.; Penuelas, J.; Field, C.B.A. Narrow-Waveband spectral index that tracks diurnal changes in photosynthetic efficiency. Remote Sens. Environ. 1992, 41, 35-44. [CrossRef]

5. Hilker, T.; Coops, N.C.; Schwalm, C.R.; Jassal, R.S.; Black, T.A.; Krishnan, P. Effects of mutual shading of tree crowns on prediction of photosynthetic light-use efficiency in a coastal Douglas-fir forest. Tree Physiol. 2008, 28, 825-834. [CrossRef] [PubMed]

6. Hilker, T.; Coops, N.C.; Hall, F.G.; Black, T.A.; Wulder, M.A.; Nesic, Z.; Krishnan, P. Separating physiologically and directionally induced changes in PRI using BRDF models. Remote Sens. Environ. 2008, 112, 2777-2788. [CrossRef]

7. Hilker, T.; Coops, N.C.; Hall, F.G.; Black, T.A.; Chen, B.; Krishnan, P.; Wulder, M.A.; Sellers, P.J.; Middleton, E.M.; Huemmrich, K.F. A modeling approach for upscaling gross ecosystem production to the landscape scale using remote sensing data. J. Geophys. Res. Biogeosci. 2008, 113. [CrossRef] 
8. Hilker, T.; Coops, N.C.; Newnham, G.J.; van Leeuwen, M.; Wulder, M.A.; Stewart, J.; Culvenor, D.S. Comparison of terrestrial and airborne LiDAR in describing stand structure of a thinned lodgepole pine forest. J. For. 2012, 110, 97-104. [CrossRef]

9. Hilker, T.; van Leeuwen, M.; Coops, N.C.; Wulder, M.A.; Newnham, G.J.; Jupp, D.L.B.; Culvenor, D.S. Comparing canopy metrics derived from terrestrial and airborne laser scanning in a Douglas-fir dominated forest stand. Trees Struct. Funct. 2010, 24, 819-832. [CrossRef]

10. Wulder, M.A.; White, J.C.; Nelson, R.F.; Næsset, E.; Ørka, H.O.; Coops, N.C.; Hilker, T.; Bater, C.W.; Gobakken, T. Lidar sampling for large-area forest characterization: A review. Remote Sens. Environ. 2012, 121, 196-209. [CrossRef]

11. Shettles, M.; Hilker, T.; Gray, A.; Temesgen, H. Examination of uncertainty in per unit area estimates of above ground biomass using terrestrial LiDAR. Can. J. For. Res. 2016, 46, 706-715. [CrossRef]

12. Zald, H.; Wulder, M.A.; White, J.C.; Hilker, T.; Hermosilla, T.; Hobart, G.W.; Coops, N.C. Integrating Landsat pixel composites and change metrics with lidar plots to predictively map forest structure and aboveground biomass in Saskatchewan, Canada. Remote Sens. Environ. 2016, 176, 188-201. [CrossRef]

13. Hilker, T.; Wulder, M.A.; Coops, N.C.; Seitz, N.; White, J.C.; Gao, F.; Masek, J.G.; Stenhouse, G. Generation of dense time series synthetic Landsat data through data blending with MODIS using a spatial and temporal adaptive reflectance fusion model. Remote Sens. Environ. 2009, 113, 1988-1999. [CrossRef]

14. Hall, F.G.; Hilker, T.; Coops, N.C. Photosynthat, photosynthesis from space: Theoretical foundations of a satellite concept and validation from tower and spaceborne data. Remote Sens. Environ. 2011, 115, 1918-1925. [CrossRef]

15. Hall, F.G.; Hilker, T.; Coops, N.C. Data assimilation of photosynthetic light-use efficiency using multi-angular satellite data: I. Model formulation. Remote Sens. Environ. 2012, 121, 301-308. [CrossRef]

16. Hilker, T.; Coops, N.C.; Hall, F.G.; Nichol, C.J.; Lyapustin, A.; Black, T.A.; Wulder, M.A.; Leuning, R.; Barr, A.; Hollinger, D.Y.; et al. Inferring terrestrial photosynthetic light use efficiency of temperate ecosystems from space. J. Geophys. Res. 2011, 116, 11. [CrossRef]

17. Lyapustin, A.I.; Wang, Y.; Lazlo, I.; Hilker, T.; Hall, F.G.; Sellers, P.J.; Tucker, C.J.; Korkin, S.V. Multi-Angle Implementation of Atmospheric Correction for MODIS (MAIAC). Part 3: Atmospheric correction. Remote Sens. Environ. 2012, 127, 385-393. [CrossRef]

18. Hilker, T.; Hall, F.G.; Coops, N.C.; Collatz, J.G.; Black, T.A.; Tucker, C.J.; Sellers, P.J.; Grant, N. Remote sensing of transpiration and heat fluxes using multi-angle observations. Remote Sens. Environ. 2013, 137, 31-42. [CrossRef]

19. Nag, S.; Gatebe, C.; Hilker, T.; Hall, F.; Dyrud, L.; de Weck, O. Gross primary productivity estimation using multi-angular measurements from small satellite clusters. In Proceedings of the 2014 IEEE International Symposium on Geoscience and Remote Sensing (IGARSS), Beijing, China, 13-18 July 2014.

20. Hilker, T.; Lyapustin, A.I.; Tucker, C.J.; Hall, F.G.; Myneni, R.B.; Wang, Y.; Bi, J.; de Moura, Y.M.; Sellers, P.J. Vegetation dynamics and rainfall sensitivity of the Amazon. Proc. Natl. Acad. Sci. USA 2014, 111, 16041-16046. [CrossRef] [PubMed]

21. Moura, Y.M.; Hilker, T.; Lyapustin, A.I.; Galvão, L.S.; Santos, J.R.; Anderson, L.O.; Sousa, C.H.R.; Arai, E. Seasonality and drought effects of Amazonian forests observed from multi-angle satellite data. Remote Sens. Environ. 2015, 171, 278-290. [CrossRef]

22. Hilker, T.; Galvão, L.S.; Aragão, L.E.O.C.; Moura, Y.M.; Amaral, C.H.; Lyapustin, A.I.; Wu, J.; Albert, L.P.; Ferreira, M.J.; Santos, V.A.H.F.; et al. Vegetation chlorophyll estimated from multi-angle MODIS and tower hyperspectral observations: A tool for scaling ecosystem seasonality and leaf demography across Amazonian evergreen forests. Remote Sens. Environ. 2016, under review.

(C) 2016 by the authors; licensee MDPI, Basel, Switzerland. This article is an open access article distributed under the terms and conditions of the Creative Commons Attribution (CC-BY) license (http://creativecommons.org/licenses/by/4.0/). 